\title{
Impact of using genotyping to predict SERF negative phenotype in Thai blood donor populations
}

\author{
Oytip Nathalang ${ }^{1}$, Kamphon Intharanut ${ }^{1}$, Nipapan Leetrakool ${ }^{2}$, Supattra Mitundee ${ }^{3}$, \\ Pawinee Kupatawintu ${ }^{4}$ \\ ${ }^{1}$ Graduate Program in Biomedical Sciences, Faculty of Allied Health Sciences, Thammasat University, Pathumtani, ${ }^{2}$ Blood Bank \\ Section, Faculty of Medicine, Chiang Mai University, Chiang Mai, ${ }^{3}$ Regional Blood Centre 12th Songkhla, Thai Red Cross Society, \\ Songkhla, ${ }^{4}$ National Blood Centre, Thai Red Cross Society, Bangkok, Thailand
}

p-ISSN 2287-979X / e-ISSN 2288-0011 https://doi.org/10.5045/br.2020.2020042 Blood Res 2020;55:107-111.

Received on March 11, 2020

Revised on March 27, 2020

Accepted on April 16, 2020
*This study was supported by a grant from Thammasat University Research Fund, Contract No. TUFT17/2562.

\section{Correspondence to}

Oytip Nathalang, Ph.D.

Graduate Program in Biomedical Sciences,

Faculty of Allied Health Sciences,

Thammasat University, Pathumtani 12120,

Thailand

E-mail: oytipntl@hotmail.com

(C) 2020 Korean Society of Hematology

\section{Background}

SERF $(+)$ is a high prevalence antigen in the Cromer blood group system that is encoded by a $C R O M^{*} 01.12$ allele. The SERF(-) on red cells is caused by a single nucleotide variation, c.647C $>$ T, in exon 5 of the Decay-accelerating factor, DAFgene. Alloanti-SERF was found in a pregnant Thai woman, and a SERF(-) individual was found among Thai blood donors. Since anti-SERF is commercially unavailable, this study aimed to develop appropriate genotyping methods for $C R O M^{*} 01.12$ and $C R O M^{*} 01 .-12$ alleles and predict the SERF(-) phenotype in Thai blood donors.

Methods

DNA samples obtained from 1,580 central, 300 northern, and 427 southern Thai blood donors were genotyped for $C R O M^{*} 01.12$ and $C R O M^{*} 01 .-12$ allele detection using in-house PCR with sequence-specific primer (PCR-SSP) confirmed by DNA sequencing.

Results

Validity of the PCR-SSP genotyping results agreed with DNA sequencing; $C R O M^{*} 01.12$ / CROM $^{*} 01.12$ was the most common $(98.42 \%, 98.00 \%$, and $98.59 \%)$, followed by CROM $^{*} 01.12 /$ CROM $^{*} 01 .-12(1.58 \%, 2.00 \%$, and $1.41 \%)$ among central, northern, and southern Thais, respectively. $C O^{*}{ }^{*} 01 .-12 / C R O M^{*} 01 .-12$ was not detected in all three populations. The alleles found in central Thais did not significantly differ from those found in northern and southern Thais.

\section{Conclusion}

This study is the first to distinguish the predicted SERF phenotypes from genotyping results obtained using in-house PCR-SSP, confirming that the $C R O M^{*} 01$.-12 allele frequency ranged from 0.007 to 0.010 in three Thai populations. This helps identify the SERF(-) phenotype among donors and patients, ultimately preventing adverse transfusion reactions.

Key Words Cromer blood group system, SERF negative phenotype, Genotyping, Thais

\section{INTRODUCTION}

Cromer (CROM) blood group system antigens are carried on the decay-accelerating factor (DAF; CD55). Twenty antigens are currently assigned to this system by the International Society of Blood Transfusion (ISBT) Working Party on Red Cell Immunogenetics and Blood Group Nomenclature [1]. SERF is a high prevalence antigen first discovered in 2004 after the identification of alloanti-SERF in a pregnant SERF-negative, SERF(-), Thai woman. This antibody reacts with reagent red cells only during the indirect antiglobulin phase, and it is nonreactive with $\alpha$-chymotrypsin-treated red cells [2, 3]. The genetic basis of the SERF antigen has already been determined. This antigen is encoded by the CROM*01.12 allele. The lack of the SERF antigen (CROM*01.-12 allele) on red cells, otherwise known as the SERF(-) phenotype, is caused by a single nucleotide variation (SNV), i.e., 
c.647C $>$ T, which encodes p. Pro216Leu in exon 5 of the $D A F$ gene. Polymerase chain reaction (PCR)-restriction fragment length polymorphism (RFLP) was developed to analyze the SERF alleles in 1,041 Thai blood donors owing to the unavailability of human antiserum. One donor homozygous for $C R O M^{*} 01 .-12$ and 21 donors heterozygous for CROM*01.12 $C R O M^{*} 01 .-12$ were identified [4]. However, this rare allele has not been investigated in other populations. The absence of the SERF antigen could be restricted to an ethnic group.

In Thailand, the National Blood Centre of the Thai Red Cross Society revealed that $24.6 \%$ out of 2,821 patients who underwent an antibody identification test received a result called unidentified specificity, which arises due to a low-titer antibody in the work-up or due to the lack of extra cells with rare phenotypes [5]. The initial screening for $\mathrm{Jk}(\mathrm{a}-\mathrm{b}-)$, a rare phenotype, uses the urea lysis test, and confirmation through testing with anti- $\mathrm{Kk}^{\mathrm{a}}$ and $-\mathrm{Jk}^{\mathrm{b}}$ is a cost-effective method [6]. In the Augustine blood group system, the PCR-sequence-specific primer (PCR-SSP) could differentiate between $\operatorname{At}(\mathrm{a}+)$ and $\operatorname{At}\left(\mathrm{a}^{-}\right)$when identifying the $\operatorname{At}\left(\mathrm{a}^{-}\right)$phenotype despite the limited availability of antiserum. $\operatorname{At}(\mathrm{a}-)$ is a rare phenotype restricted among Africans [7].

After more than a decade, only one case of the SERF(-) phenotype was reported in a related study involving the Thai population [4]. Blood transfusions are required to find a patient with an unidentified antibody specificity who is a suspected anti-SERF case. All stakeholders in blood transfusion services face a considerable challenge in finding compatible and safe transfusions for alloimmunized patients. This study aimed to develop appropriate genotyping methods for the $C R O M^{*} 01.12$ and $C R O M^{*} 01 .-12$ alleles and predict the SERF(-) phenotype in the studied Thai populations.

\section{MATERIALS AND METHODS}

\section{Blood samples and controls}

EDTA-anticoagulated peripheral venous blood samples were collected from 2,307 unrelated healthy blood donors. Overall, 1,580, 300, and 427 samples were obtained from donors who came from central, northern, and southern Thailand, respectively. Genomic DNA was extracted from all samples using a Genomic DNA extraction kit (REAL
Genomics, RBCBioscience, Taipei, Taiwan) and stored at $-20^{\circ} \mathrm{C}$ until used for genotyping. Informed consent was obtained from each subject. This study was approved by the Committee on Human Rights Related to Research Involving Human Subjects of the Thammasat University, Pathumtani, Thailand (COE No. 034/2561).

\section{DNA sequencing}

200 genomic DNA blood samples were sequenced to identify the $C R O M^{*} 01.12$ and $C R O M^{*} 01 .-12$ alleles. A 600 bp fragment containing the SNV (c.647C $>$ T, rs144692928) in the $D A F$ gene was obtained by PCR amplifying genomic DNA using the SEQ SERF_600_F forward primer and the SEQ SERF_600_R reverse primer (Table 1). For each PCR reaction, $2 \mu \mathrm{L}$ of genomic DNA $(50 \mathrm{ng} / \mu \mathrm{L})$ was amplified in a total volume of $50 \mu \mathrm{L}$ using $3 \mu \mathrm{L}$ of $10 \mu \mathrm{M}$ forward primer and $3 \mu \mathrm{L}$ of $10 \mu \mathrm{M}$ reverse primer. PCR was performed using $25 \mu \mathrm{L}$ of $2 \mathrm{X}$ PCR reaction mixture (Phusion High-Fidelity PCR Master Mix, New England BioLabs, MA, USA) and $17 \mu \mathrm{L}$ of sterile distilled water in a T100 Thermal Cycler (Bio-Rad Laboratories, Inc., Hercules, CA, USA).

PCR was performed under the following conditions. Initial denaturation was conducted at $98^{\circ} \mathrm{C}$ for $30 \mathrm{~s}$. The PCR program began with 10 cycles of $10 \mathrm{~s}$ at $98^{\circ} \mathrm{C}$ and $60 \mathrm{~s}$ at $69^{\circ} \mathrm{C}$ followed by 20 cycles of $30 \mathrm{~s}$ at $98^{\circ} \mathrm{C}, 60 \mathrm{~s}$ at $62^{\circ} \mathrm{C}$, and $30 \mathrm{~s}$ at $72^{\circ} \mathrm{C}$. The last step was a final extension for $5 \mathrm{~min}$ at $72^{\circ} \mathrm{C}$. The PCR products were electrophoresed at 100 volts on a $1.5 \%$ agarose gel containing $10,000 \mathrm{X}$ fluorescent DNA gel stain (SYBR Safe DNA Gel Stain, Invitrogen, Paisley, UK) in $1 \mathrm{X}$ TBE buffer. The products were visualized using a blue light transilluminator. The PCR products were subsequently purified using a gel extraction kit (GeneJET Gel Extraction Kit, Thermo Scientific, MA, USA), and the eluted fragments were sequenced (U2Bio Sequencing Service, Bangkok, Thailand) using the abovementioned PCR primers.

\section{Genotyping of the CROM*OI.I2 and CROM*OI.-12 alleles} using PCR-SSP

The $C R O M^{*} 01.12$ and $C R O M^{*} 01 .-12$ alleles were genotyped using the PCR-SSP technique. Primers were designed using Primer3 and BLAST. Briefly, $1 \mu \mathrm{L}$ of genomic DNA $(50 \mathrm{ng} / \mu \mathrm{L})$ was amplified in a total volume of $10 \mu \mathrm{L}$ using $10 \mu \mathrm{M}$ SERF_C+_F forward primer $(1 \mu \mathrm{L})$ and $10 \mu \mathrm{M}$ SERF_R

Table 1. Primer sequences for $C R O M^{*} 01.12$ and $C R O M^{*} 01 .-12$ genotyping.

\begin{tabular}{|c|c|c|c|}
\hline Allele detected & Primer & Primer sequence $\left(5^{\prime} 3^{\prime}\right)$ & Product size (bp) \\
\hline $\mathrm{CROM}^{*} 01.12$ & $\begin{array}{l}\text { SERF_C }+ \text { F } \\
\text { SERF_R }\end{array}$ & $\begin{array}{l}\text { TCTGTCCAGTGGAGTGACCC } \\
\text { AАCTTGCTGGTTTATCTTCACAGC }\end{array}$ & 235 \\
\hline $\mathrm{CROM}^{*} 01 .-12$ & $\begin{array}{l}\text { SERF_T-_F } \\
\text { SERF_R }\end{array}$ & $\begin{array}{l}\text { TCTGTCCAGTGGAGTGACCT } \\
\text { AACTTGCTGGTTTATCTTCACAGC }\end{array}$ & 235 \\
\hline$H G H$ & $\begin{array}{l}\mathrm{HGH}-\mathrm{F} \\
\mathrm{HGH}-\mathrm{R}\end{array}$ & $\begin{array}{l}\text { TGCСТTСССААССАТTСССТTA } \\
\text { ССАСТСАСGGАTTTСТGTTGTGTTTC }\end{array}$ & 434 \\
\hline$D A F$ & $\begin{array}{l}\text { SEQ_SERF_600_F } \\
\text { SEQ_SERF_600_R }\end{array}$ & $\begin{array}{l}\text { CTTTCTAACATATTCCCCATGCAAA } \\
\text { TGACCAAGTGCAATACAAACCT }\end{array}$ & 600 \\
\hline
\end{tabular}


reverse primer $(1 \mu \mathrm{L})$ for $C R O M^{*} 01.12$ allele detection and $10 \mu \mathrm{M}$ SERF_T-_F forward primer $(1 \mu \mathrm{L})$ and SERF_R reverse primers $(1 \mu \mathrm{L})$ for $C R O M^{*} 01 .-12$ allele detection. Co-amplification of the human growth hormone $(H G H)$ gene using $10 \mu \mathrm{M}$ HGH-F forward primer $(1 \mu \mathrm{L})$ and $10 \mu \mathrm{M} H G H-\mathrm{R}$ reverse primer $(1 \mu \mathrm{L})$ was performed as the internal control. Table 1 shows the sequences of the primer combinations in the two primer mixtures and the allele detected by each mixture. PCR was performed with $5 \mu \mathrm{L}$ of the $2 \mathrm{X}$ PCR reaction mixture (OnePCR Plus, GeneDirex, Taiwan) in a T100 Thermal Cycler (Bio-Rad Laboratories, Inc., Hercules,
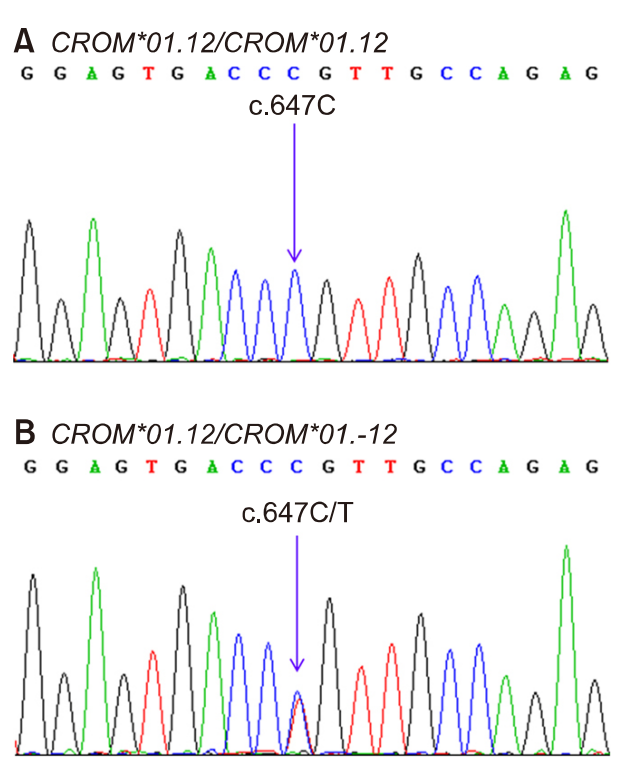

Fig. 1. Electropherograms of the $D A F$ gene at the $C R O M^{*} 01.12$ and $C R O M^{*} 01 .-12$, SNV c.647C > T. DNA sequences of the $C R O M^{*} 01.12$ homozygote (A) and the $C R O M^{*} 01.12 / C_{R O M}^{*} 01 .-12$ heterozygote (B) are amplified.
CA, USA).

PCR was performed under the following conditions. Initial denaturation was conducted at $95^{\circ} \mathrm{C}$ for $30 \mathrm{~s}$. The PCR program began with 10 cycles of $30 \mathrm{~s}$ at $95^{\circ} \mathrm{C}$ and $60 \mathrm{~s}$ at $69^{\circ} \mathrm{C}$ followed by 20 cycles of $10 \mathrm{~s}$ at $95^{\circ} \mathrm{C}, 50 \mathrm{~s}$ at $60^{\circ} \mathrm{C}$, and $30 \mathrm{~s}$ at $72^{\circ} \mathrm{C}$. The last step was the final extension of $5 \mathrm{~min}$ at $72^{\circ} \mathrm{C}$ before keeping the sample at $4^{\circ} \mathrm{C}$. The PCR products were electrophoresed at 100 volts on a $1.5 \%$ agarose gel in 1X TBE buffer. The gel was stained with SYBR Safe Stain and visualized using a blue light transilluminator. The size of the $C R O M^{*} 01.12$ and $C R O M^{*} 01 .-12$ allele PCR products were both $235 \mathrm{bp}$, and the internal control (i.e. the $H G H$ gene) was $434 \mathrm{bp}$.

The known DNA controls for the $C_{R O M}^{*} 01.12$ and $C R O M^{*}$ 01.-12 alleles were determined using DNA sequencing. Overall, a total of 2,307 DNA samples from the Thai blood donors were tested for $C R O M^{*} 01.12$ and $C R O M^{*} 01 .-12$ alleles using PCR-SSP. The genomic DNA samples from 100 genotyped blood donors (37 heterozygous CROM*01.12/ CROM*01.-12 and 63 homozygous $C R O M^{*} 01.12$ (CROM*01.12) were re-tested by PCR-SSP and sequenced to validate our in-house PCR-SSP technique for the genotyping of the CROM*01.12 and $C R O M^{*} 01 .-12$ alleles.

\section{Statistical analysis}

The gene and allele frequencies in the Thai blood donors were estimated using gene counting. The allele frequencies in central Thais were compared to northern and southern Thais using the Pearson's chi-square $\left(\chi^{2}\right)$ test. All statistical analyses were conducted using SPSS Version 16.0 (SPSS Inc., Chicago, IL, USA). A $P$-value of less than 0.05 was considered statistically significant.

In addition, the probability of finding one donor with a predicted SERF(-) phenotype was estimated. According to the Hardy-Weinberg Equilibrium (HWE) equation, $\mathrm{p}^{2}+$ $2 \mathrm{pq}+\mathrm{q}^{2}=1$, where $\mathrm{p}$ denotes the dominant allele frequency

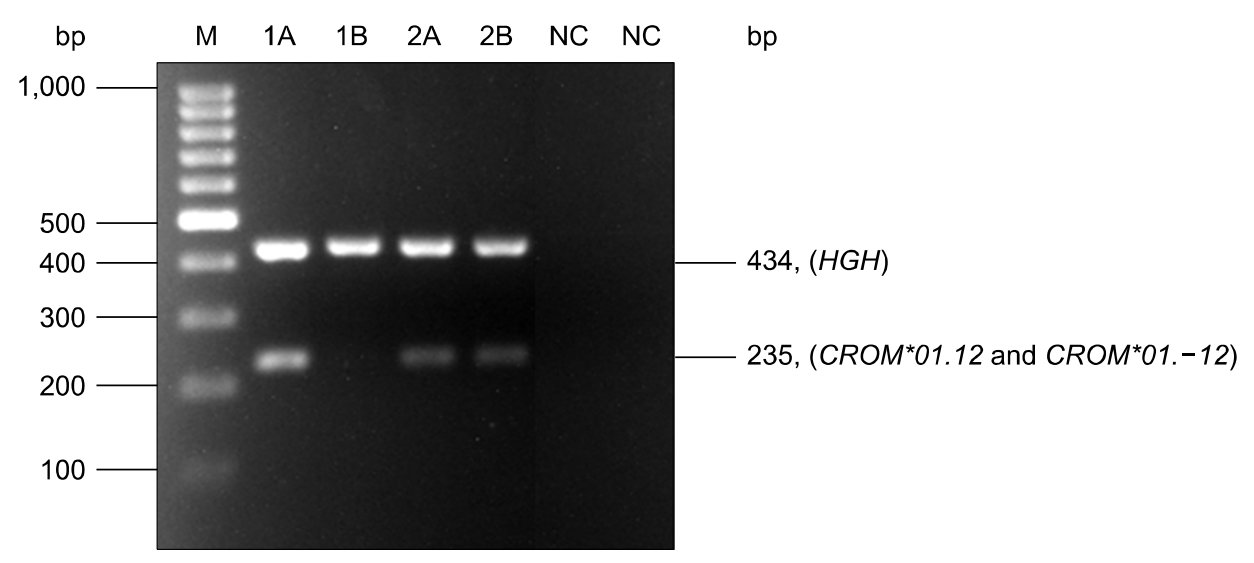

Fig. 2. A representative gel shows genotyping results of the $C R O M^{*} 01.12$ and $C R O M^{*} O 1 .-12$ alleles using the PCR-SSP technique. The 434 bp amplification product of the $\mathrm{HGH}$ control primers was present in all lanes, showing that amplification had optimally occurred. The genotype was deduced from the presence or absence of $235 \mathrm{bp}$ amplification product specific for $C R O M^{*} 01.12$ and $C R O M^{*} 01$. -12 alleles [from left to right, lanes $1 \mathrm{~A}-1 \mathrm{~B}=C R O M^{*} 01.12 / C R O M^{*} 01.12 ; 2 \mathrm{~A}-2 \mathrm{~B}=C R O M^{*} 01.12 / C R O M^{*} 01 .-12$ and $\mathrm{NC}=$ negative control, respectively; $\mathrm{M}, 100$ bp ladder marker $($ Fermentas Carlsbad, CA, USA)]. 
(CROM*01.12), $\mathrm{q}$ denotes the recessive allele frequency $\left(C R O M^{*} 01 .-12\right), \mathrm{p}^{2}$ is the frequency of the homozygous dominant allele, $\mathrm{q}^{2}$ is the frequency of the recessive allele, and $2 \mathrm{pq}$ is the frequency of the heterozygous allele [8].

The number of testing units is $1 / \mathrm{q}^{2}$.

\section{RESULTS}

The DNA sequencing results showed that four of the 200 Thai blood donors were heterozygous for $C R O M^{*} 01.12 /$ $C R O M^{*} 01$.-12, and 196 were homozygous for $C R O M^{*} 01.12$ $C R O M^{*} 01.12$ (Fig. 1). Subsequently, two sets of PCR were performed to detect the $C R O M^{*} 01.12$ and $C R O M^{*} 01 .-12$ alleles. The PCR-SSP results showed that a 235 bp product was found after using the first and second sets of primers for the $C R O M^{*} 01.12$ and $C R O M^{*} 01 .-12$ allele detection. The $H G H$ internal control showed a band of $434 \mathrm{bp}$ in each set (Fig. 2). The genotyping results for both alleles were validated using the known DNA controls obtained from the DNA sequencing, and the results in both sets showed $100 \%$ concordance.

Total of 1,580, 300, and 427 samples were obtained from the central, northern, and southern Thai blood donors, respectively. They were genotyped for $C R O M^{*} 01.12$ and CROM*01.-12 using PCR-SSP (Table 2). CROM*01.12/ $C R O M^{*} 01.12$ was the most common genotype $(98.42 \%$, $98.00 \%$, and $98.59 \%)$ followed by $C R O M^{*} 01.12 / C R O M^{*} 01 .-12$ $(1.58 \%, 2.00 \%$, and $1.41 \%)$ in the central, northern, and southern Thai blood donors, respectively. CROM*01.-12/ $C R O M^{*} 01 .-12$ was not found in the three groups. The allele frequencies of $C R O M^{*} 01.12$ in the central, northern, and southern Thais were 0.992 (3,135/3,160), 0.990 (594/600), and $0.993(848 / 854)$, respectively, whereas the frequencies of the $C_{R O M}^{*} 01 .-12$ allele were 0.008 (25/3160), 0.010 $(6 / 600)$, and 0.007 (6/854), respectively. No significant difference was observed when the detected $C R O M^{*} 01.12$ and CROM*01.-12 alleles in central Thais were compared to those detected in the northern and southern Thai blood donors (Table 2). Moreover, PCR-SSP was performed using 100 randomly selected samples including 37 samples heterozygous for $\operatorname{CROM}^{*} 01.12 / \operatorname{CROM}^{*} 01 .-12$ and 63 samples homozygous for $C R O M^{*} 01.12 / C R O M^{*} 01.12$ as confirmed by DNA sequencing. The results of the repeated testing were consistent with those of the first round of testing and were concordant with the DNA sequencing results.

According to the HWE equation, homozygous recessive individuals $\left(\mathrm{CROM}^{*} 01 .-12 / \mathrm{CROM}^{*} 01 .-12\right)$ are represented by the $\mathrm{q}^{2}$ term in the HWE equation: $0.000064(0.008 \times 0.008)$, $0.0001(0.010 \times 0.010)$, and $0.000049(0.007 \times 0.007)$ for the central, northern, and southern Thais, respectively. The probability of finding one expected donor carrying this rare allele was estimated to be 15,625 (1/0.000064), 10,000 (1/0.0001), and $20,408(1 / 0.000049)$ for the central, northern, and southern Thai populations, respectively.

\section{DISCUSSION}

Serological methods cannot always determine rare blood phenotypes owing to the limited availability of antiserum and of unmarketed products. To date, various molecular methods for red cell genotyping can be performed in blood bank laboratories to massively screen blood donors and to distinguish antibody specificity in recently transfused patients [9-13]. Given its reliability and simplicity, PCR-SSP is widely used in genotyping SNVs, especially in laboratories with limited resources [7, 14]. In Thailand, commercial kit-based red cell genotyping involving the use of PCR-sequence-specific oligonucleotide probes like $\mathrm{Jk}(\mathrm{a}-\mathrm{b}-)$, Fy(a-b+), and Di(a+b-) is employed only in specialized reference laboratories given its high cost and the need for complex equipment. However, mass screening with the aim to identify donors carrying rare phenotypes recognizes the phenotype frequency and the phenotype's clinical significance in hemolytic transfusion reactions and in hemolytic disease of the

Table 2. $C R O M^{*} 01.12$ and $C R O M^{*} 01 .-12$ genotype and allele frequencies among Thai blood donors.

\begin{tabular}{|c|c|c|c|c|c|}
\hline Allele & Allele frequencies & Genotype & Observed (\%) & $\chi^{2}(\mathrm{DF}=1)$ & $P$ \\
\hline \multicolumn{6}{|c|}{ Central Thais $(\mathrm{N}=1,580)$} \\
\hline CROM*01.12 & $3,135(0.992)$ & CROM ${ }^{*} 01.12 /$ CROM $^{*} 01.12$ & $1,555(98.42)$ & NA & NA \\
\hline \multirow[t]{2}{*}{ CROM $^{*} 01 .-12$} & $25(0.008)$ & CROM $^{*} 01.12 /$ CROM $^{*} 01 .-12$ & $25(1.58)$ & & \\
\hline & & CROM $^{*} 01 .-12 /$ CROM $^{*} 01 .-12$ & $0(0.00)$ & & \\
\hline \multicolumn{6}{|c|}{ Northern Thais $(\mathrm{N}=300)$} \\
\hline CROM $^{*} 01.12$ & $594(0.990)$ & CROM $^{*} 01.12 /$ CROM $^{*} 01.12$ & $294(98.00)$ & 0.269 & 0.604 \\
\hline \multirow[t]{2}{*}{$\mathrm{CROM}^{*} 01 .-12$} & $6(0.010)$ & CROM $^{*} 01.12 /$ CROM $^{*} 01 .-12$ & $6(2.00)$ & & \\
\hline & & CROM $^{*} 01 .-12 /$ CROM $^{*} 01 .-12$ & $0(0.00)$ & & \\
\hline \multicolumn{6}{|c|}{ Southern Thais $(N=427)$} \\
\hline CROM $^{*} 01.12$ & $848(0.993)$ & CROM $^{*} 01.12 /$ CROM $^{*} 01.12$ & $421(98.59)$ & 0.069 & 0.793 \\
\hline \multirow{2}{*}{$\mathrm{CROM}^{*} 01 .-12$} & $6(0.007)$ & CROM $^{*} 01.12 /$ CROM $^{*} 01 .-12$ & $6(1.41)$ & & \\
\hline & & CROM $^{*} 01 .-12 /$ CROM $^{*} 01 .-12$ & $0(0.00)$ & & \\
\hline
\end{tabular}

Abbreviations: DF, degree of freedom; NA, not applicable. 
fetus and newborn (HDFN). Only one case of alloanti-SERF was found (a pregnant Thai woman), and the occurrence of HDFN is unlikely because the DAF on the apical surface of trophoblasts in placenta absorbs maternal antibodies [15].

Concerning the predicament in finding SERF(-) blood donors and the shortage of data in Thai populations, this study has established that PCR-SSP could determine the $C R O M^{*} 01.12$ and $C R O M^{*} 01$.-12 alleles, and thus could predict the occurrence of the SERF(-) phenotype in the three Thai populations. A related study proposed the use of PCR-RFLP to identify the rare $C R O M^{*} 01 .-12$ allele. However, PCR-SSP is more convenient and less time consuming than PCR-RFLP with regard to screening blood donors [4]. The developed PCR-SSP could identify three genotypes: CROM $M^{*}$ 1.12/ $C R O M^{*} 01.12, C R O M^{*} 01.12 / C R O M^{*} 01 .-12$, and $C R O M^{*}$ 01.-12/ CROM*01.-12. The validated PCR-SSP genotyping results were confirmed using DNA sequencing, demonstrating the accuracy of the results. Even though a control for SERF(-) or CROM*01.-12/CROM*01.-12 was not included in this study, all heterozygous $C R O M^{*} 01.12 / C R O M^{*} 01 .-12$ results obtained using PCR-SSP were identical to DNA sequencing results. Hence, the developed PCR-SSP could predict the SERF antigen, and it is a cost-effective approach for massively screening this antigen in Thai blood donors.

The frequencies of the $C R O M^{*} 01.12$ and $C R O M^{*} 01 .-12$ alleles in central Thais were similar to those observed in northern and southern Thais. The allele frequency of CROM*01.-12 ranged from 0.007 to 0.010 , similar to a frequency of 0.011 reported in a related study involving Thai blood donors. No predicted SERF(-) donor was identified from the 2,307 samples studied. By contrast, only one rare phenotype was accidentally discovered from among the 1,041 donors screened in a related study [4]. Additionally, alloanti-SERF has not yet been reported after 2004 possibly due to the lack of reagent red cells for identification or due to its absolute absence. In using the HWE equation to estimate one donor with the $\operatorname{SERF}(-)$ phenotype, more than 10,000 donor units are required for testing. Hence, these results indicated that $C R O M^{*} 01 .-12 / C R O M^{*} 01 .-12$ is a very rare genotype in the three Thai populations.

In conclusion, this study was the first to distinguish the predicted SERF phenotypes from the genotyping results obtained using the in-house PCR-SSP. Moreover, the results showed that the frequency of the $C R O M^{*} 01 .-12$ allele in the three Thai populations ranged from 0.007 to 0.010 . Therefore, PCR-SSP is a beneficial method for identifying the SERF(-) phenotype among donors and patients and ultimately in preventing adverse transfusion reactions.

\section{Authors' Disclosures of Potential Conflicts of Interest}

No potential conflicts of interest relevant to this article were reported.

\section{REFERENCES}

1. Storry JR, Clausen FB, Castilho L, et al. International Society of Blood Transfusion Working Party on Red Cell Immunogenetics and Blood Group Terminology: Report of the Dubai, Copenhagen and Toronto meetings. Vox Sang 2019;114:95-102.

2. Banks J, Poole J, Ahrens N, et al. SERF: a new antigen in the Cromer blood group system. Transfus Med 2004;14:313-8.

3. Storry JR, Reid ME, Yazer MH. The Cromer blood group system: a review. Immunohematology 2010;26:109-18.

4. Palacajornsuk P, Hue-Roye K, Nathalang O, Tantimavanich S, Bejrachandra S, Reid ME. Analysis of SERF in Thai blood donors. Immunohematology 2005;21:66-9.

5. Kupatawintu P, Emthip M, Sungnoon D, et al. Unexpected antibodies of patients, blood samples sent for testing at NBC. TRCS. J Hematol Transfus Med 2010;20:255-62.

6. Deelert S, Thippayaboon $\mathrm{P}$, Sriwai W, et al. Jk(a-b-) phenotype screening by the urea lysis test in Thai blood donors. Blood Transfus 2010;8:17-20.

7. Nathalang O, Intharanut K, Sasikarn W, Nathalang S, Kupatawintu P. A new polymerase chain reaction: sequence-specific primer method for the Augustine blood type. Blood Transfus 2016;14: 577-9.

8. Fung MK, Eder AF, Spitalnik SL, Westhoff CM, eds. Technical manual. 19th ed. Bethesda, MD: AABB, 2017.

9. Avent ND. Large-scale blood group genotyping: clinical implications. Br J Haematol 2009;144:3-13.

10. Wagner FF, Bittner R, Petershofen EK, Doescher A, Müller TH. Cost-efficient sequence-specific priming-polymerase chain reaction screening for blood donors with rare phenotypes. Transfusion 2008;48:1169-73.

11. Gassner C, Meyer S, Frey BM, Vollmert C. Matrix-assisted laser desorption/ionisation, time-of-flight mass spectrometry-based blood group genotyping--the alternative approach. Transfus Med Rev 2013;27:2-9.

12. Latini FR, Gazito D, Arnoni CP, et al. A new strategy to identify rare blood donors: single polymerase chain reaction multiplex SNaPshot reaction for detection of 16 blood group alleles. Blood Transfus 2014;12(Suppl 1):s256-63.

13. Hong YJ, Chung Y, Hwang SM, et al. Genotyping of 22 blood group antigen polymorphisms and establishing a national recipient registry in the Korean population. Ann Hematol 2016;95:985-91.

14. Liu Z, Zeng R, Chen Q et al. Genotyping for Kidd, Kell, Duffy, Scianna, and RHCE blood group antigens polymorphisms in Jiangsu Chinese Han. Chin Med J (Engl) 2012;125:1076-81.

15. Reid M, Lomas-Francis C, Olsson M, eds. The blood group antigen factsbook. 3rd ed. London, UK: Academic Press, 2012. 